Article

\title{
Antioxidant Chemical Treatment Affects Physiology and Quality of Minimally-processed Escarole
}

\author{
Carlos Dornelles Ferreira Soares $1, * \mathbb{C}$, José Guilherme Prado Martin ${ }^{2}(0)$, \\ Natalia Dallocca Berno ${ }^{1}$ (D) and Ricardo Alfredo Kluge ${ }^{1}$ \\ 1 Luiz de Queiroz College of Agriculture (ESALQ), Biological Sciences Department, University of São \\ Paulo (USP), Piracicaba 13418-900, Brazil; natalia.berno@usp.br (N.D.B.); rakluge@usp.br (R.A.K.) \\ 2 Microbiology Department, Federal University of Viçosa (UFV), Viçosa, Minas Gerais 36570-900, Brazil; \\ guilherme.martin@ufv.br \\ * Correspondence: dornellessoares@usp.br; Tel.: +55-199-84277313
}

Received: 16 July 2019; Accepted: 14 October 2019; Published: 6 November 2019

\begin{abstract}
This study evaluated the effect of antioxidant application on quality and physiological aspects of minimally-processed escarole (Cichorium endivia var. latifolia L.) stored at $0{ }^{\circ} \mathrm{C}$ and $90-95 \%$ relative humidity for $21 \mathrm{~d}$. After minimal processing, leaves were immersed for $5 \mathrm{~min}$ in the following solutions: deionized water-control (CT), 1\% ascorbic acid (AA), $1 \%$ citric acid (CA), $1 \%$ oxalic acid $(\mathrm{OA})$, and $2 \%$ ethylenediamine-tetraacetic acid (EDTA). Excess water was removed and they were then packed in trays of expanded polystyrene and stored at $0{ }^{\circ} \mathrm{C}$ and $90-95 \%$ relative humidity for $21 \mathrm{~d}$. Analyses were performed on day 0 , after $1 \mathrm{~h}$ of processing, and then at intervals of $3 \mathrm{~d}$. The $1 \%$ CA treatment maintained the highest levels of endogenous ascorbic acid and pigment content, as well as the lowest values of weight loss and Browning Index (BI). Microbiological development was within the limits established during storage for all treatments. Total phenolic compound content and the activity of polyphenol oxidase and peroxidase enzymes showed variations among treatments. Observing all results, it was concluded that $1 \%$ CA was the best antioxidant for the maintenance of the quality attributes of minimally-processed escarole for up to $21 \mathrm{~d}$ in cold storage at $0{ }^{\circ} \mathrm{C}$.
\end{abstract}

Keywords: Cichorium endivia var. latifolia L.; enzymatic browning; phenolic compounds

\section{Introduction}

Minimally-processed products (MPP) are ready-to-eat fresh fruits or vegetables that have passed procedures such as washing, cutting or peeling, and packaging [1]. However, the processing steps cause physical and physiological changes, resulting in undesired symptoms such as off-flavors, enzymatic browning, loss of firmness and nutrients, and the development of possible pathogenic microorganisms $[2,3]$.

To prevent these symptoms and prolong the shelf life of MPP, auxiliary techniques have been used along with refrigeration techniques such as modified and controlled atmosphere, chemical treatment, irradiation, edible coatings, heat treatments, and others [3,4]. Among these, the application of antioxidants is one of the most efficient. Antioxidants decrease the respiratory rate, inhibiting the action of enzymes that cause browning and loss of nutrients and pigments. Some of them also have an antimicrobial effect. The use of antioxidants consists of immersing the product into solutions containing organic acids, minerals, or combinations of both [3-9].

The most commonly used organic acids are ascorbic, citric, salicylic, and oxalic, and ethylenediamine tetracetic acid (EDTA). These acids are relatively weak, are recognized as safe for food application and consumption, and are widely used in MPP. They are considered mainly as antibrowning and antioxidant 
agents, but their efficiency may vary according to their concentration and chemical compostition, justifying the study of the effects of the application of each one in vegetables $[4,8-10]$.

Escarole (Cichorium endivia var. latifolia L.) and lettuce are the most popular leafy vegetables, and are consumed in salads [11]. Escarole is perfect for the MPP market, considering its nutritional properties and the demand for healthy foods that are easy to prepare or ready-to-eat. It has several antioxidant compounds that help prevent diseases, such as flavonoids, carotenoids, and a diversity of phenolic compounds. It is also a good source of vitamins A, B, C, and D [12-15]. However, this vegetable needs to be studied more regarding its post-processing preservation and changes in its quality attributes as a MPP. A study has verified that minimally-processed escarole showed browning of its leaves and was also sensitive to high $\mathrm{CO}_{2}$ concentrations [16]. The aim of this study was to evaluate the effect of different chemical treatments on the physiological, nutritional, and microbiological aspects of minimally-processed escarole.

\section{Materials and Methods}

\subsection{Material Preparation and Experimental Setup}

Escarole (Cichorium endivia var. latifolia L. cv. Amazonas Gigante) heads were obtained from a conventional producer located in Piracicaba, São Paulo, Brazil ( $22^{\circ} 43^{\prime} 30^{\prime \prime}$ S, 47 $37^{\circ} 38^{\prime} 51^{\prime \prime}$ W; $524 \mathrm{~m}$ altitude). They were harvested $65 \mathrm{~d}$ after planting, during the winter season, transported to the laboratory on ice, and then stored at $15^{\circ} \mathrm{C}$ and $90-95 \%$ relative humidity for $24 \mathrm{~h}$ until processing. Escarole heads were selected for similarity of size, color, and absence of diseases or mechanical and pathological damage.

The selected heads were cut to separate leaves, which were washed with running water to remove soil, passed through a new selection as described above, and held in a cold room at $15^{\circ} \mathrm{C}$. Entire leaves were sanitized by immersion in sodium hypochlorite solution $2 \%$ at $5{ }^{\circ} \mathrm{C}$ for $10 \mathrm{~min}$. After sanitization, leaves were cut manually into strips (about $2 \mathrm{~cm}$ width and $10 \mathrm{~cm}$ length) with stainless steel knives.

The leaves were again sanitized by immersion in sodium dichloroisocyanurate solution $2 \%$ at $5{ }^{\circ} \mathrm{C}$ for $5 \mathrm{~min}$, and were then immersed in the following solutions (w/v) for $5 \mathrm{~min}$ : deionized water-control (CT), $1 \%$ ascorbic acid (AA), $1 \%$ citric acid (CA), $1 \%$ oxalic acid (OA), and $2 \%$ ethylenediaminetetraacetic acid (EDTA). The concentrations of the antioxidant solutions were based on the best results for leafy MPP reported in the literature $[4,8,17]$.

After the treatments, leaves were centrifuged for $1.5 \mathrm{~min}$ in a laboratory centrifuge (Arno, Sao Paulo, SP, Brazil) with an average angular speed of $760 \times \mathrm{g}$ to remove excess water. After that, $150 \mathrm{~g}$ of the leaves were packed in $14 \mu \mathrm{m}$ PVC plastic film on trays of expanded polystyrene $(21 \times 14.5 \times 1.5 \mathrm{~cm})$, which were heat-sealed at the bottom of the trays. All samples were stored in a cold room at $0{ }^{\circ} \mathrm{C}$ and 90-95\% relative humidity for $21 \mathrm{~d}$. The temperature for storage was chosen from previous experiments; no chilling injury at $0{ }^{\circ} \mathrm{C}$ was observed. Additionally, this temperature was the best to maintain product quality aspects longer.

Analyses were performed on day 0 , after processing and then following intervals of $3 \mathrm{~d}$ until the 21st day of the experiment (the time when some treatments were still within the established limits of microbiological analysis and Browning index (BI)).

\subsection{Analysis}

\subsubsection{Browning Index, Enzymes, and Total Phenolic Compounds}

BI was calculated by the relation between visual classification of browning and the area of the affected leaf. Samples with a BI higher than 2 were considered unmarketable [18].

The extract used for enzyme analyses was based on the method used by Zhan et al. [19]. Leaf tissue $(0.5 \mathrm{~g})$ was homogenized with $12 \mathrm{~mL} 50 \mathrm{mM}$ sodium phosphate buffer ( $\mathrm{pH}$ 7.0) (on ice) and 
subsequently centrifuged at $20,000 \times g$ for $20 \mathrm{~min}$ at $4{ }^{\circ} \mathrm{C}$. The enzyme activity of the supernatant was used for the following assays.

The polyphenol oxidase activity (PPO, EC 1.10.3.2) was assayed according to the methodology proposed by Degl'Innocenti et al. [20] and modified by Zhan et al. [19]. Extract supernatant $(0.1 \mathrm{~mL})$ was mixed with $1.9 \mathrm{~mL} 25 \mathrm{mM}$ catechol. As a PPO enzymatic unit, the minimum difference in absorbance at $480 \mathrm{~nm}$ of 0.001 per minute over 10 min between readings on a spectrophotometer (Biochrom, model Libra S22) was considered. The results were expressed as PPO units per mg protein ( $\mathrm{U} \mathrm{mg}^{-1}$ protein).

For peroxidase activity (POD, EC 1.11.1.7), the methodology of Degl'Innocenti et al. [20] was used. Extract supernatant $(0.16 \mathrm{~mL})$ was mixed with $0.004 \mathrm{~mL}$ of distilled water, $0.2 \mathrm{~mL} 35 \mathrm{mM}$ hydrogen peroxide, and $1.6 \mathrm{~mL} 10 \mathrm{mM}$ guaiacol. As a POD unit, the minimum increase in absorbance at $470 \mathrm{~nm}$ of 0.001 per minute over $10 \mathrm{~min}$ was considered. The results were expressed in micromoles of guaiacol oxidized per minute per $\mathrm{mg}$ protein ( $\mathrm{mmoL}$ guaiacol $\mathrm{min}^{-1} \mathrm{mg}^{-1}$ protein).

Protein analysis was performed by the method of Bradford [21]; the extract was prepared by homogenizing $0.5 \mathrm{~g}$ of sample with $1.5 \mathrm{~mL}$ of distilled water and centrifuged at $20,000 \times \mathrm{g}$ at $4{ }^{\circ} \mathrm{C}$ for $10 \mathrm{~min}$. After that, $0.02 \mathrm{~mL}$ of the supernatant was pipetted into $0.78 \mathrm{~mL}$ of distilled water, and then $0.2 \mathrm{~mL}$ of Bradford reagent was added. After $2 \mathrm{~min}$, the samples were read at $595 \mathrm{~nm}$. The calculation of protein was carried out by a standard curve using bovine serum albumin.

Total phenolic compound (TPC) content was adapted from the method of Singleton and Rossi [22]. Extracts were prepared by homogenizing $1 \mathrm{~g}$ of sample with $9 \mathrm{~mL} 100 \%$ ethanol and centrifuged at $15,000 \times g$ at $4{ }^{\circ} \mathrm{C}$ for $20 \mathrm{~min}$. Extract supernatant $(0.3 \mathrm{~mL})$ was mixed with $0.75 \mathrm{~mL}$ of $10 \%(\mathrm{v} / \mathrm{v})$ Folin-Ciocalteu reagent, $1.20 \mathrm{~mL}$ of distilled water and $0.75 \mathrm{~mL} 4 \%(\mathrm{w} / \mathrm{v})$ sodium carbonate, this mixture was incubated for 2 hours in the dark. Samples were measured at $765 \mathrm{~nm}$ in triplicate. The calculation of total phenolic compounds was carried out using a standard curve with gallic acid. The results were expressed in $\mathrm{mg}$ of gallic acid equivalents per $100 \mathrm{~g}$ of fresh weight (mg gallic acid equivalents $\left.100 \mathrm{~g}^{-1} \mathrm{FW}\right)$.

\subsubsection{Ascorbic Acid, Total Chlorophyll, and Total Carotenoids Content}

The ascorbic acid content was extracted and analyzed using the method of Carvalho et al. [23]. Extracts were prepared by homogenizing $30 \mathrm{~g}$ of processed escarole with $10 \mathrm{~mL}$ of distilled water. This mixture was filtered through 4 layers of cheesecloth to obtain a liquid extract. Extract supernatant $(10 \mathrm{~mL})$ was mixed with $50 \mathrm{~mL}$ of $10 \%(\mathrm{w} / \mathrm{v})$ oxalic acid and then, titred with 2,6-dichlorophenol indolfenol-sodium (DCFI) indicator until it reached a persistent pink color for $15 \mathrm{~s}$. The results were expressed in $\mathrm{mg}$ of ascorbic acid per $100 \mathrm{~g}$ fresh weight $\left(100 \mathrm{mg} \mathrm{g}^{-1} \mathrm{FW}\right)$.

For quantification of total chlorophyll and total carotenoid content, cut leaves $(0.25 \mathrm{~g})$ was homogenized with an $80 \%$ acetone solution and centrifuged at $10,000 \times \mathrm{g}$ for $10 \mathrm{~min}$ at $4{ }^{\circ} \mathrm{C}$. The supernatant was used for the spectrophotometric measurement of pigments by absorbance at 663 , 646 and $470 \mathrm{~nm}$. The values of total chlorophyll and total carotenoids contents were calculated [24], and the results were expressed as milligrams of the pigment per $100 \mathrm{~g}$ fresh weight $\left(100 \mathrm{mg} \mathrm{g}^{-1} \mathrm{FW}\right)$.

\subsubsection{Gas Concentration and Weight Loss}

The concentrations of gases in the inner space of the packages were monitored every $3 \mathrm{~d}$ for $21 \mathrm{~d}$ of cold storage using a gas analyzer (CheckMate $9900 \mathrm{O}_{2} / \mathrm{CO}_{2}$ PBI Dansensor (Minneapolis, MN, USA). The gas samples were taken through a syringe coupled to a silicone septum previously fixed in the packages. The results were expressed as percentage of $\mathrm{CO}_{2}$ and $\mathrm{O}_{2}$. At day 0 , the analyses were made after $1 \mathrm{~h}$ of processing.

The weight loss was determined by the difference of the initial weight of the samples with the weight values obtained at each experimental evaluation period. The results were expressed in percentage of mass loss. 


\subsubsection{Microbiological Analyses}

Analyses were performed regarding the presence or absence of Salmonella at the beginning of the experiment and counts of psychrotrophic and coliform bacteria during the experiment. The detection of Salmonella in $25 \mathrm{~g}$ of the product was performed by procedures established by Brazilian legislation, Collegiate Board Resolution (CBR) No. 12 of 2001 of the National Health Surveillance Agency (ANVISA) legislation [25]. Counts of psychrotrophic microrganisms in samples were performed according Cousin et al. [26], and the results were expressed in log colony-forming unit per g sample (log $\mathrm{CFU} \mathrm{g}{ }^{-1}$ ). The total coliform count was performed using the Simplate Coliform kit (Biocontrol Systems) validated method by the Association of Official Analytical Chemists (AOAC) Official Method 2005.03. The results were expressed in log most probable number per $g$ sample $\left(\log \mathrm{g}^{-1} \mathrm{MPN}\right)$. There are no recommendations for the maximum amounts of total coliforms and psychrotrophic microorganisms in minimally-processed products in Brazil; hence, in this research, the value of $7 \log \mathrm{CFU} \mathrm{g}{ }^{-1}$ sample was taken as the safety threshold. This value is the international standard used by European countries.

\subsection{Statistical Analyses}

The experimental design was completely randomized in a factorial scheme of five treatments and eight periods of analysis, including time zero (after processing). There were three independent replicate samples of each treatment used for every assessed variable at each sampling time. The results were submitted to ANOVA, with averages compared by Tukey's test at $P \leq 0.01$ and $P \leq 0.05$. The data were analyzed by the Pearson correlation coefficient $(r)$ to consider significant correlations between variables, with $r$ values $>0.700$ considered significant $(P<0.01)$. Statistical analyses were performed using the statistical software Statistical Analysis System Model 9.3 [27].

\section{Results and Discussion}

\subsection{Effect of Antioxidant Treatment on Browning Index}

The treatments CT, AA, and CA showed BI within the acceptable limit until the 21st day, and no significant differences were observed between them (Figure 1A). There was an increase in BI of the leaves for the OA and EDTA treatments starting from the 9th day, which both were discarded on the 18th day, because the BI exceeded the commercial limit of browning.

The color deterioration kinetics in our research were in accordance with previous reports, such as MPP lettuce cultivars, which exceeded the visual quality limit in the 12 th day of storage at $5{ }^{\circ} \mathrm{C}$, exhibiting symptoms of severe darkening on the surfaces and cut areas of the leaves [28]. Among several factors that caused these changes in color, the most significant were enzymatic activity and pigment degradation [5].

The total phenolic compounds (TPC) (Figure 1B) showed variations during storage days. TPC content in samples ranged from 48 to $117 \mathrm{mg}$ GAE $100 \mathrm{~g}^{-1} \mathrm{FW}$, similar values to those obtained by Tiveron et al. [13] in several leafy vegetables. From the 9th day of storage, the highest values $(P<0.01)$ of TPC were observed in EDTA samples, and at the end of the experiment, CT and the treatments AA and CA showed the highest values. EDTA as a complexing and chelating agent may have maintained higher TPC values up to the 9 th day.

Variations in TPC of MPP may occur due to many aspects such as prolonged storage, temperature, and processing. After a cut in processing, the reactions of the defense mechanisms of the vegetable tissue caused the consumption of the phenolic compounds as substrates by defense enzymes; free conversions can also occur between phenolic groups and their bonds [29-32]. The application of antioxidant products in MPP affects the TPC, that may increase or decrease, depending on the chemical action and its concentration $[10,33]$. 

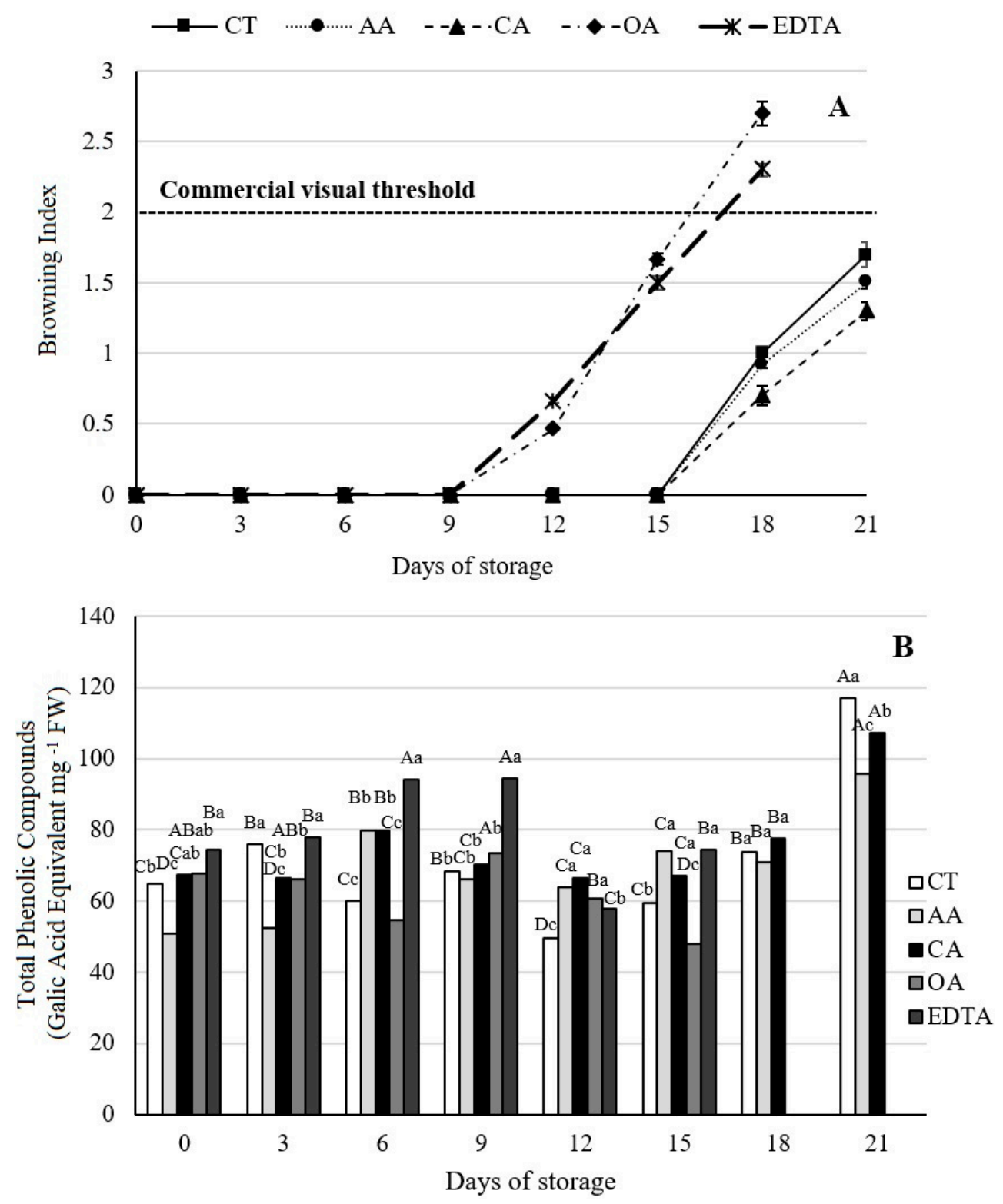

Figure 1. Browning index (BI) (A) and total phenolic compounds (TPC) (mg Gallic Acid Equivalents $\left.100 \mathrm{~g}^{-1} \mathrm{FW}\right)(\mathbf{B})$ in minimally-processed escarole treated with antioxidants and stored at $0{ }^{\circ} \mathrm{C}$ and $90-95 \%$ relative humidity for $21 \mathrm{~d}$. Vertical bars represent the standard deviation of the mean $(n=3)$. Means followed by different uppercase letters within each day of storage and lowercase letters between treatments differ from each other by Tukey's test $(P \leq 0.01)$. CT: control; AA: $1 \%$ ascorbic acid; CA: $1 \%$ citric acid; OA: $1 \%$ oxalic acid; and 2\% EDTA: ethylenediaminetetraacetic acid.

There were variations in the PPO activity (Figure 2A) during storage. Differences $(P<0.01)$ were observed among the treatments starting from the 6th day; more specifically, samples submitted to OA and EDTA treatments showed reduced activity of this enzyme. At 12 and $15 \mathrm{~d}$, the lowest PPO activity observed was for the CA and EDTA treatments. On the last day of the experiment, CA showed a lower PPO activity than AA and the control. The activity of the PPO in MPP escarole varied between 0.10 and $0.90 \mathrm{U} \mathrm{mg}^{-1}$ protein, and can be characterized as very low compared to the values obtained in lettuce cultivars, which may vary between 14 and $28 \mathrm{U} \mathrm{mg}^{-1}$ protein [34]. 



Figure 2. Polyphenoloxidase activity ( $\mathrm{U} \mathrm{mg}^{-1}$ protein) (A) and peroxidase activity ( $\mu \mathrm{mol}$ guaiacol $\mathrm{min}^{-1} \mathrm{mg}^{-1}$ protein) (B) in minimally-processed escarole treated with antioxidants and stored at $0{ }^{\circ} \mathrm{C}$ and $90-95 \%$ relative humidity for 21 days. The columns represent the average of three replicates. Means followed by different uppercase letters within each day of storage and lowercase letters between treatments differ from each other by Tukey's test $(P \leq 0.01)$. CT: control; AA: $1 \%$ ascorbic acid; CA: $1 \%$ citric acid; OA: $1 \%$ oxalic acid; and 2\% EDTA: ethylenediaminetetraacetic acid.

PPO is an oxidoreductase enzyme with copper in its active site; in the presence of oxygen, it catalyzes the hydroxylation of monophenols into $o$-diphenols, which are subsequently oxidized into $o$-quinones. These quinones can be polymerized or combined with amide compounds and carbonyl-amine or react with amino acids or proteins, thus forming dark colored, low molecular weight compounds $[10,35]$. EDTA as well as CA and OA are chelating agents, and they act on PPO, complexing with copper in its active site. The efficacy and mechanisms of action of various antioxidants depend on the vegetable species and cultivar, since PPO may use different phenolic compounds as substrates [8].

There were peaks in the POD activity (Figure 2B) in the escarole leaves during storage. In most of the storage period, the POD activity was higher $(P<0.01)$ in CT samples until the 18th day, and this treatment did not differ between AA and CA through the end of the experiment. The POD activity 
varied from 0.47 to $3.13 \mu \mathrm{mol}$ guaiacol $\mathrm{min}^{-1} \mathrm{mg}^{-1}$ protein, higher than the variation obtained in lettuce of 0.10 to $0.35 \mu \mathrm{mol}$ guaiacol $\mathrm{min}^{-1} \mathrm{mg}^{-1}$ by Altunkaya and Gökmen [36].

POD in the presence of $\mathrm{H}_{2} \mathrm{O}_{2}$ oxidizes phenolic compounds that are hydrogen donors [37,38]. When oxidized, the phenolic compounds become dark. The ascorbic acid and citric acid control the activity of POD by reducing the intracellular $\mathrm{pH}$. However, this reduction depends on the agent and the $\mathrm{pH}$ of the solution [39]. Some studies have shown that AA has a temporary antibrowning inhibitory effect because it does not act directly on the enzyme; rather, it reduces the $o$-quinones into their precursor forms of diphenols, and, in the process, the AA is converted into DHA [10,40]. On the other hand, $\mathrm{CA}$ reduces $\mathrm{pH}$, has a chelating function, and acts directly on the enzymes [41]. There are some contradictions in the literature about the POD function in browning of MPP $[7,39]$. It has been hypothesized that the formation of quinones generated by PPO can lead to the accumulation of significant levels of $\mathrm{H}_{2} \mathrm{O}_{2}$, thus allowing for the oxidation of polyphenols by POD enzyme [42,43].

The protective action of AA on TPC can be attributed to reduction reactions and regeneration of polyphenols, while CA reduces their oxidation due to its acidifying and chelating action on enzymes that use these compounds as substrates [36,44]. There are controversies regarding the involvement of phenolic compounds and the activity of enzymes in browning of MPP. Several papers have reported that there is no clear relationship between phenolic content, ascorbic acid content, and activities of PPO and POD with browning of the leaves in different cultivars of MPP lettuce $[20,45,46]$. The browning observed in MPP escarole in our research may have been caused by the degradation of chlorophyll, and microbiological growth and weight loss, in addition to enzymatic activity. This hypothesis was supported by the correlation between the values of the traits (Table 1).

Table 1. Pearson correlation $(r)$ between the traits. R values $>0.7$ were significant at $P<0.01$.

\begin{tabular}{cc}
\hline Analyses & $r$ \\
\hline Ascorbic acid content vs. total chlorophyll & 0.872 \\
Ascorbic acid content vs. total carotenoids & 0.866 \\
Weight loss vs. Browning index & 0.772 \\
Weight loss vs. ascorbic acid content & -0.800 \\
Weight loss vs. total chlorophyll & -0.888 \\
Weight loss vs. carotenoids & -0.887 \\
Ascorbic acid content vs. psychrotrophic bacteria growth & -0.821 \\
\hline
\end{tabular}

\subsection{The Conservation of Endogenous Ascorbic Acid Prevents Pigments Loss}

Ascorbic acid content (Figure 3A) decreased in all treatments during storage. The AA and CA treatments showed the highest retention $(P<0.01)$ of endogenous ascorbic acid content during storage. The OA and EDTA treatments showed values similar to the control. The ascorbic acid values in this study varied from 23.2 to $13.6 \mathrm{mg} 100 \mathrm{~g}^{-1} \mathrm{FW}$ during storage. Escarole has high ascorbic acid content if compared with lettuce cultivars, which may vary from 1.5 to $12.3 \mathrm{mg} 100 \mathrm{~g}^{-1} \mathrm{FW}$ [11]. Both AA and CA may have acted synergistically in the preservation and increasing of ascorbic acid content. In several studies, it has been reported that the increase and better retention of endogenous ascorbic acid for MPP occurred when treated with AA solutions [4,17].

Studies on the biochemical mechanism of browning in MPP leafy vegetables have reported the possible involvement of a high endogenous content of ascorbic acid as a natural antibrowning agent $[39,46,47]$. The degradation of ascorbic acid may be related to non-enzymatic browning, due to its oxidation into DHA. The DHA can subsequently react with aldol or amine groups, which are responsible for condensation of the quinone and conversion into dark compounds [48]. DHA levels have been positively correlated with browning in lettuce [49]. Vegetables with high endogenous ascorbic acid content are able to control the accumulation of reactive oxygen species (ROS) effectively. AA is a more efficient agent against the action of ROS than phenolic compounds, which controls only part of the ROS formed [50]. 

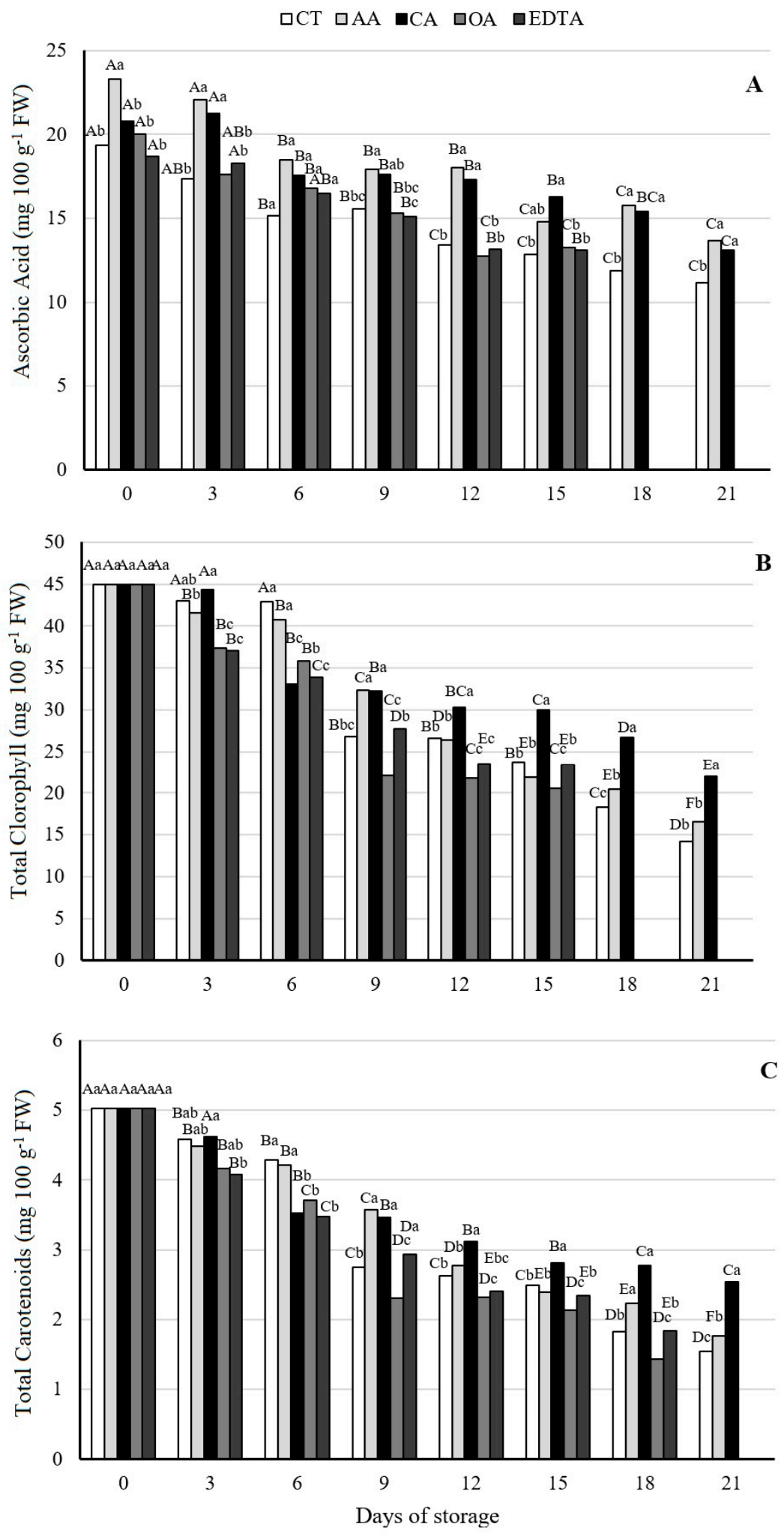

Figure 3. Ascorbic acid content (mg $\left.100 \mathrm{~g}^{-1} \mathrm{FW}\right)$ (A), total chlorophyll (mg $100 \mathrm{~g}^{-1} \mathrm{FW}$ ) (B), and total carotenoids (mg $100 \mathrm{~g}^{-1} \mathrm{FW}$ ) (C) in minimally-processed escarole, treated with antioxidants and stored at $0{ }^{\circ} \mathrm{C}$ and $90-95 \%$ relative humidity, for 21 days. The columns represent the average of three replicates. Means followed by different uppercase letters within each day of storage and lowercase letters between treatments differ from each other by Tukey's test $(P \leq 0.01)$. CT: control; AA: $1 \%$ ascorbic acid; CA: $1 \%$ citric acid; OA: $1 \%$ oxalic acid; and 2\% EDTA: ethylenediaminetetraacetic acid. 
CA was the most effective treatment for the retention of chlorophyll content (Figure 3B) and carotenoids (Figure $3 C$ ), showing the highest values $(P<0.01)$ of these pigments during storage. The total chlorophyll values in the MPP escarole were similar to those found in rocket and baby spinach (40-50 mg $100 \mathrm{~g}^{-1} \mathrm{FW}$ ) [9]. The carotenoid levels obtained were lower than those observed in lettuce,

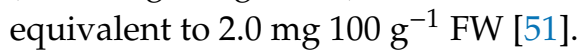

There was a positive correlation between the AA content of samples and chlorophyll and carotenoid content with $r=0.872$ and $r=0.866$, respectively (Table 1). CA and AA have exhibited similar mechanisms against pigment deterioration, reducing chemical and biochemical reactions that oxidize chloroplast structures [52]. The application of exogenous CA acts synergistically with the endogenous AA content of tissues. Considering that citric acid controls PPO, there is less demand for the consumption of ascorbic acid, which ends up being used for other purposes, as in its competitive action in the enzymatic reactions that result in brown compounds, thus preventing the loss of color and pigments $[33,53]$.

\subsection{Influence of Treatments on Escarole Metabolism}

There were differences in $\mathrm{O}_{2}$ (Figure $4 \mathrm{~A}$ ) and $\mathrm{CO}_{2}$ (Figure 4B) concentrations inside the package between treatments during storage. The treatments OA and EDTA had significantly lower $\mathrm{CO}_{2}$ concentrations $(P<0.01)$ starting from the 12th day and significantly higher concentrations of $\mathrm{O}_{2}$ $(P<0.05)$ throughout the entire storage period than the other treatments, reaching values close to that of air $(20.9 \%)$. This might have accelerated the metabolic processes of these samples, increasing the deterioration rate and thus the BI, explaining in part why they were discarded earlier than the others.

The reduction of the respiratory rate by the application of OA is associated with the decrease in metabolic activity reported in MP rocket and spinach [9]. The effect of EDTA on the respiratory rate has not been fully elucidated, but this treatment could have reduced MPP escarole respiration through its chelating action on lipids, inhibiting oxidation $[54,55]$.

The samples treated with AA had the lowest $(P<0.05) \mathrm{O}_{2}$ concentration $(17.6 \%)$ until the 21st day, during which no significant differences were observed. AA and CA treatments maintained the highest $\mathrm{CO}_{2}$ values $(P<0.01)$ until the 21th day, when they differed from the $\mathrm{CA}$. The samples immersed in $\mathrm{CA}$ showed similar $\mathrm{CO}_{2}$ reduction inside packages to the OA and EDTA treatments. CA application may cause reactions in the cytosol, reducing phosphofructokinase activity, thus also reducing glycolysis and respiration rate. The decrease in glycolysis may also be associated with the reduction of intracellular $\mathrm{pH}$ caused by CA [56].

The weight loss $(\mathrm{WL})$ was higher $(P<0.01)$ for both OA and EDTA treatments, which reached percentages of 0.66 and $0.59 \%$, respectively, at the 15th day (Figure $4 \mathrm{C}$ ); this might be explained due to the higher concentration of $\mathrm{O}_{2}$ contained inside the headspace of these samples, which could have accelerated metabolism and senescence processes. There were no differences among the other treatments during storage. The values of WL in our research were lower than previous studies of application of organic acid treatments in MPP leafy vegetables, which have varied from 0.5 to $4.2 \%$ [2].

We observed a relationship between WL and the other parameters (Table 1). WL has a high correlation with several quality factors in fruits and vegetables, such as appearance, texture, and nutritional value. There was a positive correlation between WL and BI; when WL increased, there was a reduction in firmness and increase of wilting and darkening of tissues [57]. A negative correlation with ascorbic acid content, chlorophyll, and carotenoids was also verified. At a very high degree, the loss of water could rupture the cell wall, which would cause the decompartmentalization and consequently the contact of the enzyme ascorbate oxidase with the ascorbic acid, thus decreasing the content of this acid [58]. 



Figure 4. Concentration of oxygen (A) and carbon dioxide (B) within the packaging and weight loss (\%) (C) of minimally-processed escarole with antioxidants and stored at $0{ }^{\circ} \mathrm{C}$ and $90-95 \%$ relative humidity for 21 days. Vertical bars represent the standard error of the mean $(n=3)$. The means represent the average of 3 replicates. Means followed by different uppercase letters within each day of storage and lowercase letters between treatments differ from each other by Tukey's test $(P \leq 0.01)$. CT: control; AA: $1 \%$ ascorbic acid; CA: $1 \%$ citric acid; OA: 1\% oxalic acid; and 2\% EDTA: ethylenediaminetetraacetic acid. 


\subsection{Effect of Treatments on Microbiological Growth}

No Salmonella in $25 \mathrm{~g}$ of MPP escarole was detected, which means that the MPP escarole followed the good production practices and hygiene, according to the Brazilian legislation of the National Health Surveillance Agency [25]. For total coliform analysis (Figure 5A) and psychrotrophic bacteria (Figure 5B) during storage, it was observed that both did not exceed the threshold value ( 7 log CFU g ${ }^{-1}$ ) regardless of treatment. The results also indicated the absence of fecal coliforms in the samples.


Figure 5. Total coliforms $\left(\log \mathrm{MPN} \mathrm{g}^{-1}\right)(\mathbf{A})$ and psychrotrophic bacteria $\left(\log \mathrm{CFU} \mathrm{g}{ }^{-1}\right)(\mathbf{B})$ in leaves of minimally-processed escarole treated with different antioxidants and stored at $0{ }^{\circ} \mathrm{C}$ and $90-95 \%$ relative humidity for 21 days. CT: control; AA: 1\% ascorbic acid; CA: $1 \%$ citric acid; OA: $1 \%$ oxalic acid; and 2\% EDTA: ethylenediaminetetraacetic acid.

The total coliforms in the OA and EDTA treatments showed higher values than the others starting from the 12th day. This probably occurred because of the gas concentrations inside these samples, which might have favored the development of these microorganisms. The other treatments showed similar values until the end of storage. We observed the constant and similar growth of the psychrotrophic bacteria among treatments throughout storage. There was a negative 
correlation between the content of ascorbic acid and psychrotrophic bacterial growth (Table 1), indicating that microbiological growth might have occurred due to the consumption of nutrients as substrates, which could also be related to the browning of the escarole. The count as well as the growth of microrganisms in our research followed a trend similar to previous work testing the efficiency of organic acids as sanitizers in MPP lettuce [6].

\section{Conclusions}

Based on our results, $1 \%$ citric acid treatment was the most efficient antioxidant for preserving the quality attributes of minimally-processed escarole for $21 \mathrm{~d}$ in storage at $0^{\circ} \mathrm{C}$. This treatment maintained a low browning index and microbiological growth and preserved higher levels of chlorophyll, carotenoids, and endogenous ascorbic acid. Due to the Brazilian market and the temperature variation that can occur during marketing $\left(12\right.$ to $\left.15^{\circ} \mathrm{C}\right)$, minimally-processed products are commercialized with a shelf life of up to five days. However, in this research we aimed to study the effect of the application of antioxidants and to verify which of them could conserve the quality aspects of the MPP escarole longer under ideal temperature conditions. We concluded that the application of $1 \%$ citric acid at an industrial level could be advantageous to the market for the conservation of visual and nutritional aspects, estimating that these could be better preserved for up to the sixth day of storage. For future research, we suggest testing the application of $1 \%$ citric acid at market temperatures of 10,12 , and $15^{\circ} \mathrm{C}$ and, based on microbiological and other quality analyses, establishing the commercial shelf life of the product.

Author Contributions: The authors contributed to the work as follows: conceptualization: C.D.F.S. and R.A.K.; methodology: C.D.F.S., N.D.B., and J.G.P.M.; investigation: C.D.F.S. and R.A.K.; resources: R.A.K. and J.G.P.M.; data curation: C.D.F.S. and R.A.K.; writing—original draft preparation: C.D.F.S.; writing—review and editing: R.A.K., J.G.P.M., and N.D.B.; supervision: R.A.K; project administration: C.D.F.S. and R.A.K.; funding acquisition: R.A.K.

Funding: This research was funded by Fundação de Amparo à Pesquisa do Estado de São Paulo-FAPESP (2012/01167-3 and 2016/01201-8).

Conflicts of Interest: The authors declare no conflict of interest.

\section{References}

1. Goyeneche, R.; Agueero, M.V.; Roura, S.; Di Scala, K. Application of citric acid and mild heat shock to minimally-processed sliced radish: Color evaluation. Postharvest Biol. Technol. 2014, 93, 106-113. [CrossRef]

2. Manolopoulou, E.; Varzakas, T. Effect of storage conditions on the sensory quality, colour and texture of fresh-cut minimally-processed cabbage with the addition of ascorbic acid, citric acid and calcium chloride. Food Nutr. Sci. 2011, 2, 956-963. [CrossRef]

3. Hernández, A.E.; Márquez Cardozo, C.J.; Restrepo Flores, C.E.; Cano Salazar, J.A.; Patiño Gómez, J.H. Aplicación de tratamiento térmico, recubrimiento comestible y baño químico como tratamientos poscosecha para la conservación de hortalizas mínimamente procesadas. Acta Agron. 2014, 63, 1-10. [CrossRef]

4. Kluge, R.A.; Geerdink, G.M.; Tezotto-Uliana, J.V.; Danelon Guassi, S.; Zorzeto, T.Q.; Cerqueira Sasaki, F.F.; Mello, S.D.C. Qualidade de pimentões amarelos minimamente processados tratados com antioxidantes. Semina Ciênc. Agrar. 2014, 25, 801-811. [CrossRef]

5. Ihl, M.; Aravena, L.; Scheuermann, E.; Uquiche, E.; Bifani, V. Effect of immersion solutions on shelf-life of minimally-processed lettuce. LWT_Food Sci. Technol. 2003, 36, 591-599. [CrossRef]

6. Akbas, M.Y.; Olmez, H. Effectiveness of organic acid, ozonated water and chlorine dippings on microbial reduction and storage quality of fresh-cut iceberg lettuce. J. Sci. Food Agric. 2007, 87, 2609-2616. [CrossRef]

7. Oms-Oliu, G.; Rojas-Graue, M.A.; Gonzalez, L.A.; Varela, P.; Solivafortuny, R.; Hernando, M.I.H.; Munuera, I.P. Recent approaches using chemical treatments to preserve quality of fresh-cut fruit: A review. Postharvest Biol. Technol. 2010, 57, 139-148. [CrossRef]

8. Suttirak, W.; Manurakchinakorn, S. Potential application of ascorbic acid, citric acid and oxalic acid for browning inhibition in fresh-cut fruits and vegetables. Walailak J. Sci. Technol. 2010, 7, 5-14.

9. Cefola, M.; Pace, B. Application of oxalic acid to preserve the overall quality of rocket and baby spinach leaves during storage. J. Food Process. Preserv. 2015, 39, 2523-2532. [CrossRef] 
10. Altunkaya, A.; Gökmen, V. Effect of various inhibitors on enzymatic browning, antioxidant activity and total phenol content of fresh lettuce (Lactuca sativa). Food Chem. 2008, 107, 1173-1179. [CrossRef]

11. Llorach, R.; Martinez-Sanchez, A.; Tomas-Barberan, F.A.; Gil, M.I.; Ferreres, F. Characterization of polyphenols and antioxidant properties of five lettuce varieties and escarole. Food Chem. 2008, 108, 1028-1038. [CrossRef] [PubMed]

12. Aherne, S.A.; O'Brien, N.M. Dietary flavonols: Chemistry, food content, and metabolism. Nutrition 2002, 18 , 75-81. [CrossRef]

13. Tiveron, A.P.; Melo, P.S.; Bergamaschi, K.B.; Vieira, T.M.F.S.; Regitano-D'Arce, M.A.B.; Alencar, S.M. Antioxidant activity of Brazilian vegetables and its relation with phenolic composition. Int. J. Mol. Sci. 2012, 13, 8943-8957. [CrossRef] [PubMed]

14. Mascherpa, D.; Carazzone, C.; Marrubini, G.; Gazzani, G.; Papetti, A. Identification of phenolic constituents in Cichorium endivia Var. crispum and Var. latifolium salads by high-performance liquid chromatography with diode array detection and electrospray ionization tandem mass spectrometry. J. Agric. Food Chem. 2012, 60, 12142-12150. [CrossRef]

15. Azevedo-Meleiro, C.H.; Rodriguez-Amaya, D.B. Carotenoids of endive and New Zealand spinach as affected by maturity, season and minimal processing. J. Food Compos. Anal. 2005, 18, 845-855. [CrossRef]

16. Soares, C.D.F.; de luca Sarantópoulos, C.I.G.; Kluge, R.A. Passive modified atmosphere affects the quality of minimally-processed escarole. J. Food Process. Preserv. 2018, 42, e13724. [CrossRef]

17. Evangelista, R.M.; Vieites, R.L.; Castro, P.S.; Rall, V.L. Qualidade de couve-chinesa minimamente processada e tratada com diferentes produtos. Ciênc. Tecnol. Aliment. 2009, 29, 324-332. [CrossRef]

18. Pen, L.T.; Jiang, Y.M. Effects of chitosan coating on shelf life and quality of fresh-cut Chinese water chestnut. LWT-Food Sci. Technol. 2003, 36, 359-364. [CrossRef]

19. Zhan, L.J.; Fontana, E.; Tibaldi, G.; Nicola, S. Qualitative and physiological response of minimally-processed garden cress (Lepidium sativum L.) to harvest handling and storage conditions. J. Food Agric. Environ. 2009, 7, 43-50.

20. Degl'innocenti, E.; Guidi, L.; Pardossi, A.; Tognoni, F. Biochemical study of leaf browning in minimally-processed leaves of lettuce (Lactuca sativa L. var. acephala). J. Agric. Food Chem. 2005, 53, 9980-9984. [CrossRef]

21. Bradford, M. A rapid and sensitive method for the quantitation of microgram quantities of protein utilizing the principle of protein-dye binding. Anal. Biochem. 1976, 72, 248-254. [CrossRef]

22. Singleton, V.L.; Rossi, J.A. Colorimetry of total phenolics with phosphomolybdic phosphotungstic acid reagents. Am. J. Enol. Viticult. 1965, 16, 144-158.

23. Carvalho, C.R.L.; Mantovani, D.M.B.; Carvalho, P.R.N.; Moraes, R.M. Análises Químicas: Manual Técnico, 1st ed.; ITAL: Campinas, Brazil, 1990; pp. 80-92.

24. Lichtenthaler, H.K. Chlorophylls and carotenoids: Pigments of photosynthetic biomembranes. Methods Enzymol. 1987, 148, 350-382. [CrossRef]

25. ANVISA-National Health Surveillance Agency. Resolution 12/01, Technical Regulation on Microbiological Standards for Food; ANVISA: Brasilia, Brazil, 2011.

26. Cousin, M.A.; Jay, J.M.; Vasavada, P.C. Psychrotrophic microrganisms. In Compendium of Methods for the Microbiological Examination of Foods, 4th ed.; Downes, F.P., Ito, K., Eds.; American Public Health Association: Washington, DC, USA, 2001; Volume 1, pp. 159-166.

27. SAS Institute Inc. SAS/QC ${ }^{\circledR} 9.3$ User's Guide; SAS Institute Inc.: Cary, NC, USA, 2011.

28. López-Gálvez, G.; Saltveit, M.; Cantwell, M. The visual quality of minimally-processed lettuces stored in air or controlled atmosphere with emphasis on romaine and iceberg types. Postharvest Biol. Technol. 1996, 8, 179-190. [CrossRef]

29. Ferrante, A.; Maggiore, T. Chlorophyll a fluorescence measurements to evaluate storage time and temperature of Valeria-nella leafy vegetables. Postharvest Biol. Technol. 2007, 45, 73-80. [CrossRef]

30. Boo, H.O.; Heo, B.G.; Gorinstein, S.; Chon, S.U. Positive effects of temperature and growth conditions on enzymatic and antioxidant status in lettuce plants. Plant Sci. 2011, 181, 479-484. [CrossRef]

31. Zhang, L.K.; Lu, Z.X.; Lu, F.X.; Bie, X.M. Effect of gamma irradiation on qualitymaintaining of fresh-cut lettuce. Food Control 2006, 17, 225-228. [CrossRef]

32. Martínez-Sánchez, A.; Tudela, J.A.; Luna, C.; Allende, A.; Gil, M.I. Low oxygen levels and light exposure affect quality of fresh-cut Romaine lettuce. Postharvest Biol. Technol. 2011, 59, 34-42. [CrossRef] 
33. Altunkaya, A.; Gökmen, V. Effect of various anti-browning agents on phenolic compounds profile of Fresh lettuce (L. sativa). Food Chem. 2009, 117, 122-126. [CrossRef]

34. Zhan, L.; Yu, L.; Jingiang, H.; Pang, L.; Huiping, F. Browning inhibition and quality preservation of fresh-cut romaine lettuce exposed to high intensity light. Innov. Food Sci. Emerg. Technol. 2012, 14, 70-76. [CrossRef]

35. Zawistowski, J.; Biliaderis, C.G.; Eskin, N.A.M. Polyphenoloxidases. In Oxidative Enzymes in Foods, 1st ed.; Robinson, D.S., Eskin, N.A.M., Eds.; Elsevier: London, UK, 1991; pp. 217-273.

36. Altunkaya, A.; Gökmen, V. Purification and characterization of polyphenoloxidase, peroxidase and lipoxygenase from freshly cut lettuce (L. sativa). Food Technol. Biotechnol. 2011, 49, 249-256.

37. Richard-Forget, F.C.; Gauillard, F.A. Oxidation of chlorogenic acid, catechins, and 4-methylcatechol in model solutions by combinations of pear (Pyrus communis Cv. Williams) polyphenoloxidase and peroxidase: A possible involvement of peroxidase in enzymatic browning. J. Agric. Food Chem. 1997, 45, 2472-2476. [CrossRef]

38. Robinson, D.S. Peroxidases and their significance in fruits and vegetables. In Food Enzymology, 1st ed.; Fox, P.F., Ed.; Elsevier: London, UK, 1991; pp. 399-426.

39. Landi, M.; Degl'innocenti, E.; Guglielminetti, L.; Guidi, L. Role of ascorbic acid in the inhibition of polyphenoloxidase and the prevention of browning in different browning-sensitive Lactuca sativa var. capitata (L.) and Eruca sativa (Mill.) stored as fresh-cut produce. J. Sci. Food Agric. 2013, 93, 1814-1819. [CrossRef] [PubMed]

40. Nicolas, J.J.; Richard-Forget, F.C.; Goupy, P.M.; Amiot, M.J.; Aubert, S.Y. Enzymatic browning reactions in apple and apple products. Crit. Rev. Food Sci. Nutr. 1994, 34, 109-157. [CrossRef] [PubMed]

41. Son, S.M.; Moon, K.D.; Lee, C.Y. Kinetic study of oxalic acid inhibition on enzymatic browning. J. Agric. Food Chem. 2000, 48, 2071-2074. [CrossRef] [PubMed]

42. Jiang, Y.; Miles, P.W. Generation of $\mathrm{H}_{2} \mathrm{O}_{2}$ during enzymic oxidation of catechin. Phytochemistry 1993, 33, $29-34$. [CrossRef]

43. Subramanian, N.; Venkatesh, P.; Ganguli, S.; Sinkar, V.P. Role of polyphenoloxidase and peroxidase in the generation of black tea thea flavins. J. Agric. Food Chem. 1999, 47, 2571-2578. [CrossRef]

44. Kayashima, T.; Katayama, T. Oxalic acid is available as a natural antioxidant in some systems. Biochim. Biophys. Acta 2002, 1573, 1-3. [CrossRef]

45. Cantos, E.; Espín, J.C.; Tomás-Barberá, F.A. Effect of wounding on phenolic enzymes in six minimallyprocessed lettuce cultivars upon storage. J. Agric. Food Chem. 2001, 49, 322-330. [CrossRef]

46. Degl'innocenti, E.; Pardossi, A.; Tognoni, F.; Guidi, L. Physiological basis of sensitivity to enzymatic browning in 'lettuce', 'escarole' and 'rocket salad' when stored as fresh-cut products. Food Chem. 2007, 104, 209-215. [CrossRef]

47. Bottino, A.; Degl'innocenti, E.; Guidi, L.; Graziani, G.; Fogliano, V. Bioactive compounds during storage of fresh-cut spinach: The role of endogenous ascorbic acid in the improvement of product quality. J. Agric. Food Chem. 2009, 57, 2925-2931. [CrossRef] [PubMed]

48. Sapers, G.M.; Hicks, K.B.; Miller, R.L. Antibrowning agents. In Food Additives, 2nd ed.; Branen, A.L., Davidson, P.M., Salminen, S., Thorngate, J.H., III, Eds.; CRC Press: New York, NY, USA, 2001; pp. 545-546.

49. Heimdal, H.; Kuhn, B.F.; Poll, L.; Larsen, L.M. Biochemical changes and sensory quality of shredded and MA-packaged Iceberg lettuce. J. Food Sci. 1995, 60, 1265-1276. [CrossRef]

50. Reyes, L.F.; Villarreal, J.E.; Cisneros-Zevallos, L. The increase in antioxidant capacity after wounding depends on the type of fruit or vegetable tissue. Food Chem. 2007, 101, 1254-1262. [CrossRef]

51. Ferrante, A.; Martinetti, L.; Maggiore, T. Biochemical changes in cut vs. intact lamb's lettuce (Valerianella olitoria) leaves during storage. Int. J. Food Sci. Technol. 2009, 44, 1050-1056. [CrossRef]

52. Thompson, J.E.; Legge, R.L.; Barber, R.F. Tansley review 8: The role of free-radicals in senescence and wounding. New Phytol. 1987, 105, 317-344. [CrossRef]

53. Ansorena, R.M.; Moreira, R.M.; Roura, S.I. Combined effect of ultrasound, mild heat shock and citric acid to retain greenness, nutritional and microbiological quality of minimally-processed broccoli (Brassica oleracea L.): An optimization study. Postharvest Biol. Technol. 2014, 91, 1-13. [CrossRef]

54. Azeredo, H.M.C.; Brito, E.S.; Garruti, D.S. Alterações químicas em alimentos durante a estocagem. In Fundamentos de Estabilidade de Alimentos, 2nd ed.; Azeredo, H.M.C., Ed.; EMBRAPA: Brasília, Brazil, 2012; Volume 1, pp. 39-75. 
55. Chaiyasit, W.; Elias, R.J.; McClements, D.J.; Decker, E.A. Role of physical structures in bulk oils on lipid oxidation. Crit. Rev. Food Sci. Nutr. 2007, 47, 299-317. [CrossRef]

56. Kato-Noguchi, H.; Watada, A.E. Citric acid reduces the respiration of fresh-cut carrots. HortScience 1997, $32,136$. [CrossRef]

57. do Nascimento Nunes, M.C. Correlations between subjective quality and physicochemical attributes of fresh fruits and vegetables. Postharvest Biol. Technol. 2015, 107, 43-54. [CrossRef]

58. Proulx, E.; Yagiz, Y.; Nunes, M.C.N.; Emond, J.P. Quality attributes limiting snap bean (Phaseolus vulgaris L.) postharvest life at chilling and non-chilling temperatures. HortScience 2010, 45, 1238-1249. [CrossRef]

(C) 2019 by the authors. Licensee MDPI, Basel, Switzerland. This article is an open access article distributed under the terms and conditions of the Creative Commons Attribution (CC BY) license (http://creativecommons.org/licenses/by/4.0/). 